\title{
Effect of Dry Spells on Growth and Yield of Field Pea under Irrigated Condition
}

\author{
Govind Pandey ${ }^{1}$, A. Pradhan ${ }^{1 *}$, M. Kumar ${ }^{2}$, T. Chandrakar ${ }^{3}$ and D. P. Singh ${ }^{4}$ \\ ${ }^{1}$ Department of Natural Resource Management, ${ }^{2}$ Department of Agronomy, \\ ${ }^{3}$ Department of Soil Science, ${ }^{4}$ Department of Agri. Statistics, \\ S. G. CARS, IGKV, Jagdalpur, India \\ *Corresponding author
}

\begin{tabular}{l}
\hline Ke y w o r d s \\
$\begin{array}{l}\text { Dry spells, field } \\
\text { pea, growth \& } \\
\text { yield, moisture } \\
\text { stress, irrigation }\end{array}$ \\
\hline Article Info \\
\hline $\begin{array}{l}\text { Accepted: } \\
\text { 12 May } 2021 \\
\text { Available Online: } \\
\text { 10 June } 2021\end{array}$ \\
\hline
\end{tabular}

\section{A B S T R A C T}

Field pea is a legume most commonly consumed all over the world and is very popular in the vegetarian diets because of high levels of amino acids, lysine and tryptophan presence in it as compared to cereals. A field experiment was carried out in Inceptisols of Midland AICRPDA, during rabi 2020-21 in Instructional cum Research Farm, S.G. College of Agriculture and Research Station, I.G.K.V., Kumhrawand, Jagdalpur, Chhattisgarh, India lies at $19^{\circ} 5^{\prime} 17.79^{\prime \prime} \mathrm{N}$ latitude and $81^{\circ} 57^{\prime} 44.99^{\prime \prime} \mathrm{E}$ longitude with an altitude of 552 meters above mean sea level. The experiment consists of five treatments viz., 20 days dry spell at 40 days after sowing, at flower initiation, after $50 \%$ flowering, Irrigation at $20 \%$ soil moisture and control (Three irrigation) were laid out in Randomized Complete Block Design (RCBD) with four replications during rabi season of 2020-21. The higher plant height $(54.27 \mathrm{~cm})$, leaf area index (5.16), crop growth rate (0.400), days to flower (46.00), number of tendril (41.45) and root volume $(6.208 \mathrm{v} / \mathrm{v}$ at 60 DAS) were observed with irrigation at $20 \%$ soil moisture being at par to 20 days dry spell after $50 \%$ flowering (54.12, 5.93, 0.378, 45.9, 41.15 and 6.175). The higher chlorophyll $a$ and $b$ were noticed under control (0.724 and 0.234) and found on par with irrigation at $20 \%$ soil moisture (0.678 and 0.132) during dry spell. The higher root volume was observed under the treatment where irrigation $20 \%$ soil moisture was done. The maximum branches was with 20 days dry spell after $50 \%$ flowering (4.5 and 52.2), whereas, more number of pods recorded (8.80) and seeds per pod (4.65) were recorded under control. Nitrogen uptake was significantly superior under control $\left(70.21 \mathrm{~kg} \mathrm{ha}^{-1}\right)$, phosphorus $\left(7.58\right.$ and kg ha $\left.{ }^{-1}\right)$ and potash $\left(23.80 \mathrm{~kg} \mathrm{ha}^{-1}\right)$ were also noticed with control followed by irrigation at $20 \%$ soil moisture. The maximum grain yield $\left(16.19 \mathrm{q} \mathrm{ha}^{-1}\right)$ was recorded with control (three irrigations) and found significantly superior as compared to other treatments except the two treatments viz., 20 days dry spell after $50 \%$ flowering $\left(16.03 \mathrm{q} \mathrm{ha}^{-1}\right)$ and irrigation at $20 \%$ soil moisture $\left(16.04 \mathrm{q} \mathrm{ha}^{-1}\right)$, which were statistically similar to control (three irrigations). The highest B:C ratio was recorded with control (2.01), being significantly superior and comparable to both 20 days dry spell after 50\% flowering (1.93) and irrigation at $20 \%$ soil moisture (1.89). 


\section{Introduction}

Field pea is a legume most commonly consumed all over the world and is very popular in the vegetarian diets because of high levels of amino acids, lysine and tryptophan presence in it as compared to cereals. Pea plants were first grown in the Mediterranean region in 7000 B.C. to provide food for humans and animal feed. From this origin, peas have spread over most temperate regions (McPhee, 2004) and are now grown for human consumption and for hay, or silage to support animal production (Uzun et al., 2005).On an average field contains, 93\% calories, $72 \%$ moisture, $15.9 \%$ carbohydrates and $20-22 \%$ protein in addition to $0.1 \mathrm{~g}$ fat, $9.0 \mathrm{mg}$ vitamin, $0.25 \mathrm{mg}$ thiamine, $0.01 \mathrm{mg}$ riboflavin, and $21.5 \mathrm{mg}$ mineral per $100 \mathrm{~g}$ of edible portion. When compared to soybean it contains 21 to 25 percent protein, 5 to 20 percent less trypsin inhibitors which is much higher than soybean.

Among winter season pulses, field pea is ranked second after chickpea in India (Rao et al., 2017). Most commonly field pea is marketed in the form dry, shelled product for human or food for livestock. Depending on the location sowing usually takes place from winter to early summer. Field pea is most often called "poor man's meat" due to its high protein, vitamin and mineral content which makes it easily affordable for poorer consumers and hence making it a critical economic and nutritive crop and naturally field pea is a rich source of iron and zinc because of which it can be used to treat several micronutrient deficiencies found all over the globe (Amarakoon et al., 2019). In Chhattisgarh, total gross area under pulses for 2018-19 was 734 thousand ha. In 2018 there was a production of 14530 metric ton of pea (Directorate of economics and statistics data 2020-2021, Govt. of Chhattisgarh). In 2016-17 pea was cultivated in an area of about 53720 ha with productivity of $400 \mathrm{~kg} \mathrm{ha}^{-1}$ (Anonymous, 2018). A major factor responsible for declining yield in pea is drought stress (Fougereux et al., 1997). Drought is one of the important environmental constraints that hampers the productivity and declines the quality as well as quantity of the yield of several crops (Boyer, 1982). It reduces the growth rate, elongation of stem, expansion of leaves and movement of stomata (Hsiao, 1973). The physiological and biochemical processes that govern the growth and productivity of plants are severely affected as a result of stress (Daie, 1988). Plants are exposed to different kinds of stress under field conditions which brings about different plant responses viz. additive, antagonistic and synergistic. Plants grown under moisture stress have lower conductance of stomata ultimately resulting in lower carbon dioxide fixation, photosynthetic rate resulting in declining growth and yield (Boyer, 1970). Photosynthesis in plants is inhibited under conditions of moisture stress thereby resulting in changes in the concentration of chlorophyll by destroying the photosynthetic apparatus (Iturbe Ormaetxe et al., 1998).

The effect of drought on pea depends upon its intensity, duration, and the stage of growth at which it occurs in the plant. Peas are highly sensitive to moisture stress (Salter, 1962, Stoker, 1973). There is a greater reduction in yield of pea when it is exposed to drought at the reproductive stage resulting in the abortion of flowers and pods (Maurer et al., 1968; Pumphrey and Schwanke, 1974; Salter, 1963; Stoker, 1973). The stand, growth and yield of crop is highly decreased when supply of water is limited (Ghoulam and Fares, 2001). The objective of the experiment was to investigate the influence of varying timing and intensity of drought on the growth, development, yield, quality, and water use of field peas. Keeping above views in mind elucidated the effect of dry spell in field pea. 


\section{Materials and Methods}

A field experiment was carried out in Inceptisols of Midland AICRPDA, during rabi 2020-21 Instructional cum Research Farm, S.G. College of Agriculture and Research Station, I.G.K.V., Kumhrawand, Jagdalpur, Chhattisgarh, India lies at $19^{\circ} 5^{\prime} 17.79^{\prime \prime} \mathrm{N}$ latitude and $81^{\circ} 57^{\prime} 44.99 " \mathrm{E}$ longitude with an altitude of 552 meters above mean sea level. The average annual rainfall and temperature of the area were recorded about $1621 \mathrm{~mm}$ and $24.6^{\circ} \mathrm{C}$, respectively during 2020-21. The experimental site was characterized by low in available $\mathrm{N}\left(138.07 \mathrm{~kg} \mathrm{ha}^{-1}\right)$ and available $\mathrm{P}$ $\left(7.84 \mathrm{~kg} \mathrm{ha}^{-1}\right)$; high available $\mathrm{K}\left(358.85 \mathrm{~kg} \mathrm{ha}^{-}\right.$ $\left.{ }^{1}\right), 6.7 \mathrm{pH}, 0.18 \mathrm{EC}\left(\mathrm{dS} \mathrm{m}{ }^{-1}\right), 0.52 \%$ organic carbon. The experiment consists of five treatments viz., $\mathrm{T}_{1}: 20$ days dry spell at 40 days after sowing, $\mathrm{T}_{2}: 20$ days dry spell at flower initiation, $\mathrm{T}_{3}$ : 20 days dry spell after $50 \%$ flowering, $\mathrm{T}_{4}$ : Irrigation at $20 \%$ soil moisture and $\mathrm{T}_{5}$ : control (Three irrigation) were laid out on field pea crop in Randomized Complete Block Design (RCBD) with four replications during rabi season of 2020-21.

The test variety Paras was sown in line at rows of spacing $30 \mathrm{~cm}$ and plant to plant spacing was about $10 \mathrm{~cm}$ on $21^{\text {th }}$ November 2020 and harvested on $27^{\text {th }}$ February, 2021. Chlororpyriphos 20\% EC was sprayed @ 2 $\mathrm{ml} /$ litre of water for control of pod borer and fungicide carbendazim + mancozeb to be applied @ 2g/litre of water for control of wilt in field pea. Growth parameters viz., plant height, leaf measurement, branch, tendrils, flowers, chlorophyll, along with post harvest observations were recorded. The nitrogen, phosphorus and potassium $\left(\mathrm{kg} \mathrm{ha}^{-1}\right)$ uptake was calculated by multiplying the percentage of these nutrients in grains and straw with the corresponding yields of the respective constituents. All the observations recorded of pre and post-harvest were subjected to statistical analysis of variance ratio (F-value) to test the significance of the treatment effect and the statistical analysis was subjected as per the guidelines of Gomez and Gomez (1984).

\section{Results and Discussion}

\section{Growth parameters}

The increase in plant growth parameters was more initially; thereafter it was decreased sharply. The higher plant height $(54.27 \mathrm{~cm})$, leaf area index (5.16), crop growth rate (0.400), days to flower (46.00), number of tendril (41.45) and root volume $(6.208 \mathrm{v} / \mathrm{v}$ at 60 DAS) were observed with irrigation at $20 \%$ soil moisture being at par to 20 days dry spell after 50\% flowering $(54.12,5.93,0.378,45.9$, 41.15 and 6.175) as given in Table 1. The shift of plant Initial 30 DAS of crop requires proliferation of roots which affects on plant growth, thereafter the growth parameters increased tremendously due to availability of growth resources and potential of variety. This result confirms with the findings of Dahl et al., (2012) and Semereet et al., (2001). The enhanced early vegetative growth in terms of higher plant height, LAI (The numbers of leaves were also reduced at severe-water stress condition by $28.31,30.10$ and $31.29 \%$ for the respective three cultivars. The number of branches was decreased by $30.67,37.29$ and $30.73 \%$ at the severe-water stress level. Leaf area expansion was reduced, with reference to the control, by leaf width and leaf length (Embiale et al., 2016) resulted in more number of tendrils.

\section{Chlorophyll}

The chlorophyll was analyzed on two stages of crop, during dry spell and after dry spell to assess the effect of dry spell on field pea was recorded under different treatments (Table 2). Chlorophyll $a$ and $b$ were varied significantly at both stages of observation showing higher 
during dry spell as compared to later dry spell. The higher chlorophyll $a$ and $b$ were noticed under control (0.724 and 0.234) and found on par with irrigation at $20 \%$ soil moisture $(0.678$ and 0.132 ) during dry spell; similar trend was observed after dry spell with control and irrigation at $20 \%$ soil moisture. On other hand, chlorophyll $b$ was higher in control $(0.364$ and 0.132 ) and comparable to irrigation at $20 \%$ soil moisture $(0.110$ and 0.524$)$.

Due to imposing of 20 days dry spell, whatever soil moisture available was absorbed and used into photosynthates, that possibly may be factor contributing in less dry matter production as compared to control (three irrigations) as well as irrigation at $20 \%$ soil moisture. Adequate supply of growth resources help in the increased production of larger, thick and succulent leaves due to proper meristematic activities in the cell. This turn helped the maximum utilization of sunlight and other growth factors which ultimately resulted in production of more photosynthates and translocation from leaves (Baishya et al., 2010).

\section{Root volume}

Root volume increased in 20 days dry spell after $50 \%$ flowering up to initial 60 DAS due to irrigation was given at $50 \%$ flowering in particular treatment as hampered later root proliferation. The higher root volume was observed under the treatment where irrigation $20 \%$ soil moisture was done. This is close conformity with the finding of Riley (1986).

\section{Yield attributing characters}

\section{Primary and secondary branch}

The primary and secondary branch per plant showed significant difference as dry spell treatments imposed at harvest, being maximum with 20 days dry spell after $50 \%$ flowering (4.5 and 52.2) and on par to irrigation at $20 \%$ soil moisture (4.2 and 49.9) and control (4.3 and 51.2). The minimum primary and secondary branches were noticed in 20 days dry spell at 40 days after sowing (4.1 and 49.6) (Table 3). Due to congenial climatic conditions during pod formation which facilitated efficient transport of carbohydrates from source to sink which was also reflected in higher number and weighs of pods (Semereet et al., 2001).

The figure 1 expresses that increasing trend of primary branch, which was sharp in late two stages as influenced by treatments. Figure 2 on secondary branches showed the effect of treatments, 30 days onwards quickly increased secondary branches with variability of dry spells and higher secondary branches was with control.

\section{Number of pod per plant}

Branch bearing stems produce pods and significantly more number of pods recorded under control (8.80), which was higher to the rest of treatments except 20 days dry spell after $50 \%$ flowering (7.40).

The minimum number of pod was found with 20 days dry spell at 40 days after sowing (6.90).

Field pea attained significantly higher number of pods under 20 days dry spell after $50 \%$ flowering being on par to irrigation at $20 \%$ soil moisture due to creation of moist rhizosphere during critical period (Andersen and Aremu, 1991)

\section{Seeds per pod}

Application of irrigation brought about a significant improvement on number of seeds per pod and proved significantly superior to preceding treatments (Table 3 ). 
Table.1 Effect of dry spell on growth parameters and branch of field pea

\begin{tabular}{|c|c|c|c|c|c|c|c|c|}
\hline \multirow[t]{2}{*}{ Treatment } & \multicolumn{6}{|c|}{ Growth parameters } & \multicolumn{2}{|c|}{ Branches per plant } \\
\hline & $\begin{array}{l}\text { Plant ht } \\
(\mathrm{cm}) \text { at } \\
\text { harvest }\end{array}$ & $\begin{array}{c}\text { LAI } \\
\text { at } 45 \\
\text { DAS }\end{array}$ & $\begin{array}{c}\text { CGR (g } \\
\text { plant }^{-1} \\
\text { day }^{-1} \text { ) at } \\
45-60\end{array}$ & $\begin{array}{l}\text { Days } \\
\text { to } \\
\text { flower }\end{array}$ & $\begin{array}{c}\text { No. of } \\
\text { tendril } \\
\text { at } 75 \\
\text { DAS }\end{array}$ & $\begin{array}{c}\text { Root } \\
\text { volume } \\
\text { at } 60 \\
\text { DAS }\end{array}$ & $\begin{array}{c}\text { Primary } \\
\text { Branch } \\
\text { at } 75 \\
\text { DAS }\end{array}$ & $\begin{array}{l}\text { Secondary } \\
\text { Branch at } \\
90 \text { DAS }\end{array}$ \\
\hline$T_{1}: 20$ days dry spell at 40 days after sowing & 52.93 & 5.11 & 0.366 & 45.3 & 40.55 & 5.867 & 3.80 & 47.87 \\
\hline$T_{2}: 20$ days dry spell at flower initiation & 52.76 & 4.71 & 0.356 & 44.8 & 40.70 & 6.258 & 4.15 & 50.93 \\
\hline$T_{3}: 20$ days dry spell after $50 \%$ flowering & 54.12 & 5.93 & 0.378 & 45.9 & 41.15 & 6.175 & 4.20 & 51.53 \\
\hline $\mathrm{T}_{4}:$ Irrigation at $20 \%$ soil moisture & 54.27 & 5.16 & 0.400 & 46.0 & 41.45 & 6.208 & 4.30 & 50.27 \\
\hline $\mathbf{T}_{5}:$ Control (Three irrigation) & 54.16 & 4.72 & 0.410 & 45.0 & 41.25 & 5.883 & 4.45 & 50.20 \\
\hline SEm \pm & 0.34 & 0.24 & 0.003 & 0.06 & 0.11 & 0.017 & 0.09 & 0.44 \\
\hline CD $(p=0.05)$ & 1.03 & 0.81 & 0.011 & 0.21 & 0.31 & 0.052 & 0.26 & 1.34 \\
\hline
\end{tabular}

Table.2 Effect of dry spell on chlorophyll and nutrient uptake of field pea

\begin{tabular}{|c|c|c|c|c|c|c|c|c|c|c|}
\hline \multirow[t]{3}{*}{ Treatment } & \multirow{2}{*}{\multicolumn{2}{|c|}{ Chlorophyll A }} & \multirow{2}{*}{\multicolumn{2}{|c|}{ Chlorophyll B }} & \multicolumn{6}{|c|}{ Nutrient uptake $\left(\mathrm{kg} \mathrm{ha}^{-1}\right)$} \\
\hline & & & & & \multicolumn{3}{|c|}{ Haulm $\left(\mathrm{kg} \mathrm{ha}^{-1}\right)$} & \multicolumn{3}{|c|}{ Pod $\left(\mathrm{kg} \mathrm{ha}^{-1}\right)$} \\
\hline & $\begin{array}{l}\text { During } \\
\text { dry spell }\end{array}$ & $\begin{array}{c}\text { After } \\
\text { dry } \\
\text { spell }\end{array}$ & $\begin{array}{c}\text { During } \\
\text { dry } \\
\text { spell }\end{array}$ & $\begin{array}{c}\text { After } \\
\text { dry } \\
\text { spell }\end{array}$ & $\mathbf{N}$ & $\mathbf{P}$ & $\mathbf{K}$ & $\mathbf{N}$ & $\mathbf{P}$ & $\mathbf{K}$ \\
\hline $\mathrm{T}_{1}: \mathbf{2 0}$ days dry spell at 40 days after sowing & 0.516 & 0.169 & 0.199 & 0.105 & 56.8 & 5.1 & 19.3 & 101.3 & 13.6 & 34.4 \\
\hline$T_{2}: 20$ days dry spell at flower initiation & 0.597 & 0.174 & 0.364 & 0.108 & 62.0 & 5.8 & 21.0 & 107.7 & 13.4 & 33.8 \\
\hline $\mathrm{T}_{3}: 20$ days dry spell after $50 \%$ flowering & 0.371 & 0.107 & 0.503 & 0.179 & 64.0 & 6.6 & 21.0 & 112.3 & 14.8 & 35.0 \\
\hline $\mathrm{T}_{4}:$ Irrigation at $20 \%$ soil moisture & 0.678 & 0.195 & 0.524 & 0.110 & 67.1 & 6.9 & 22.8 & 114.1 & 15.1 & 37.4 \\
\hline $\mathbf{T}_{5}:$ Control (Three irrigation) & 0.724 & 0.234 & 0.632 & 0.132 & 70.2 & 7.6 & 23.8 & 118.7 & 15.3 & 38.7 \\
\hline SEm \pm & 0.015 & 0.012 & 0.036 & 0.015 & 1.03 & 0.23 & 0.35 & 1.51 & 0.08 & 0.41 \\
\hline $\mathrm{CD}(\mathrm{p}=\mathbf{0 . 0 5})$ & 0.048 & 0.041 & 0.109 & 0.047 & 3.04 & 0.68 & 1.03 & 4.48 & 0.24 & 1.21 \\
\hline
\end{tabular}


Table.3 Effect of dry spell on branches and yield attributes of field pea

\begin{tabular}{|c|c|c|c|c|c|c|c|c|}
\hline \multirow[t]{2}{*}{ Treatment } & \multicolumn{8}{|c|}{ Yield attributing characters } \\
\hline & $\begin{array}{l}\text { Primary } \\
\text { Branch }\end{array}$ & $\begin{array}{l}\text { Secondary } \\
\text { branch }\end{array}$ & $\begin{array}{l}\text { No. of } \\
\text { leaves }\end{array}$ & $\begin{array}{l}\text { No. of } \\
\text { pod } \\
\text { plant }^{-1}\end{array}$ & $\begin{array}{c}\text { seed } \\
\text { s/po } \\
\text { d }\end{array}$ & $\begin{array}{c}\text { Seed } \\
\text { wt. } \\
\text { (g) }\end{array}$ & $\begin{array}{l}\text { Pod } \\
\text { length } \\
\text { (cm) }\end{array}$ & $\begin{array}{c}\text { Test } \\
\text { weight } \\
\text { (g) }\end{array}$ \\
\hline $\begin{array}{c}\text { T1: } 20 \text { days dry spell at } 40 \text { days after } \\
\text { sowing }\end{array}$ & 4.1 & 49.6 & 20.55 & 6.90 & 3.50 & 3.36 & 4.51 & 19.71 \\
\hline T2: 20 days dry spell at flower initiation & 4.1 & 49.9 & 23.15 & 7.15 & 3.60 & 3.85 & 4.63 & 20.06 \\
\hline T3: 20 days dry spell after $50 \%$ flowering & 4.5 & 52.2 & 26.55 & 7.40 & 3.90 & 4.13 & 4.73 & 20.20 \\
\hline T4: Irrigation at $20 \%$ soil moisture & 4.2 & 49.3 & 24.70 & 7.20 & 4.05 & 5.29 & 5.02 & 20.74 \\
\hline T5: Control (Three irrigation) & 4.3 & 51.2 & 31.70 & 8.80 & 4.65 & 5.90 & 5.19 & 21.62 \\
\hline SEm \pm & 0.06 & 0.43 & 1.73 & 0.46 & 0.25 & 0.58 & 0.15 & 0.63 \\
\hline$C D(p=0.05)$ & 0.29 & 1.32 & 5.16 & 1.41 & 0.78 & 1.78 & 0.47 & NS \\
\hline
\end{tabular}

Table.4 Effect of dry spell on yields and economics of field pea

\begin{tabular}{|c|c|c|c|c|c|c|}
\hline \multirow[t]{2}{*}{ Treatment } & \multicolumn{3}{|c|}{ Yields } & \multicolumn{3}{|c|}{ Economics (Rs./ha) } \\
\hline & $\begin{array}{c}\text { Grain } \\
\text { weight } \\
\text { (q/ha) }\end{array}$ & $\begin{array}{c}\text { Haulm } \\
\text { yield } \\
\text { (q/ha) }\end{array}$ & $\begin{array}{c}\text { Harvest } \\
\text { Index } \\
(\%)\end{array}$ & $\begin{array}{c}\text { Gross } \\
\text { Monetary } \\
\text { Returns }\end{array}$ & $\begin{array}{c}\text { Net } \\
\text { Monetary } \\
\text { Returns }\end{array}$ & $\mathrm{B}: \mathrm{C}$ \\
\hline T1: 20 days dry spell at 40 days after sowing & 14.65 & 31.75 & 31.28 & 55550 & 29180 & 1.82 \\
\hline T2: 20 days dry spell at flower initiation & 14.21 & 27.79 & 30.42 & 53130 & 27552 & 1.64 \\
\hline T3: 20 days dry spell after 50\% flowering & 16.03 & 32.19 & 32.14 & 60145 & 36629 & 1.93 \\
\hline T4: Irrigation at $20 \%$ soil moisture & 16.04 & 34.19 & 33.55 & 60678 & 30193 & 1.89 \\
\hline T5: Control (Three irrigation) & 16.19 & 36.60 & 33.83 & 61768 & 32626 & 2.01 \\
\hline SEm \pm & 0.05 & 0.65 & 0.56 & 325 & 235 & 0.04 \\
\hline$C D(p=0.05)$ & 0.17 & 2.01 & 1.71 & 1055 & 749 & 0.12 \\
\hline
\end{tabular}


Fig.1 Trend of primary branch as influenced by treatments.

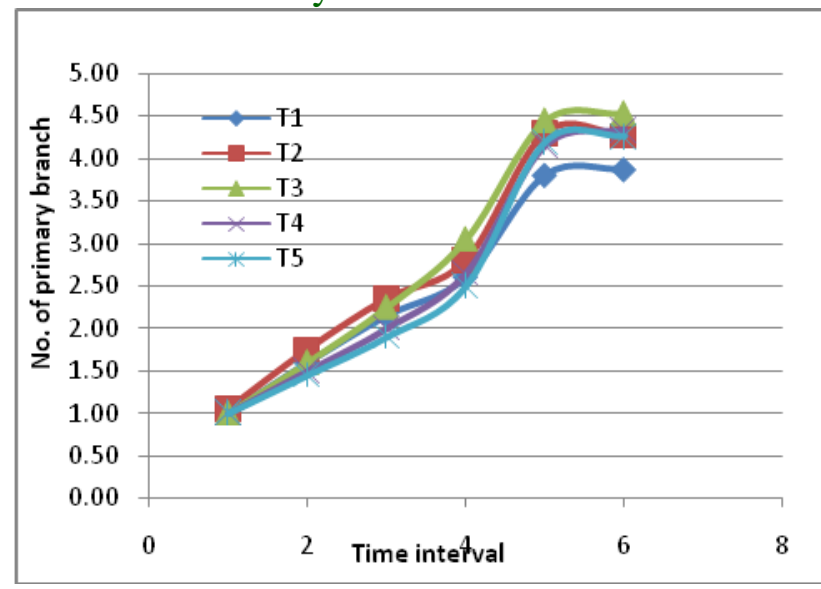

The significantly higher number of seeds per pod was recorded under control (4.65) and statistically similar with both 20 days dry spell after $50 \%$ flowering (3.90) and irrigation at $20 \%$ soil moisture (4.05). The minimum number of pod was found with 20 days dry spell at 40 days after sowing (3.50). Greater decrease in sound seeds and increase in unsound seeds under delayed irrigations might be due to the occurrence of moisture stress which resulted in declined phtotosynthesis from source to sink (Singh and Bhatti, 2013). Photosynthetic inhibition has been reported as one of the primary detrimental effects of water stress (Flexas and Mendrano, 2002; Lawlor and Crnic, 2002).

\section{$\mathbf{N}, \mathbf{P}$ and $\mathrm{K}$ uptake in grain and haulm}

\section{Haulm and pods}

The data on nutrient uptake by haulm and pods were found significant in case of nitrogen, phosphorus and potash under various treatments of dry spell in field pea (Table 2). Pods had comparatively higher value than haulm in respect to nitrogen, phosphorus and potash. Nitrogen uptake was significantly superior under control $\left(70.21 \mathrm{~kg} \mathrm{ha}^{-1}\right)$ followed by irrigation at $20 \%$ soil moisture (67.11 $\mathrm{kg} \mathrm{ha}^{-1}$ ) and both were proved
Fig.2 Effect of dry spells on secondary branches

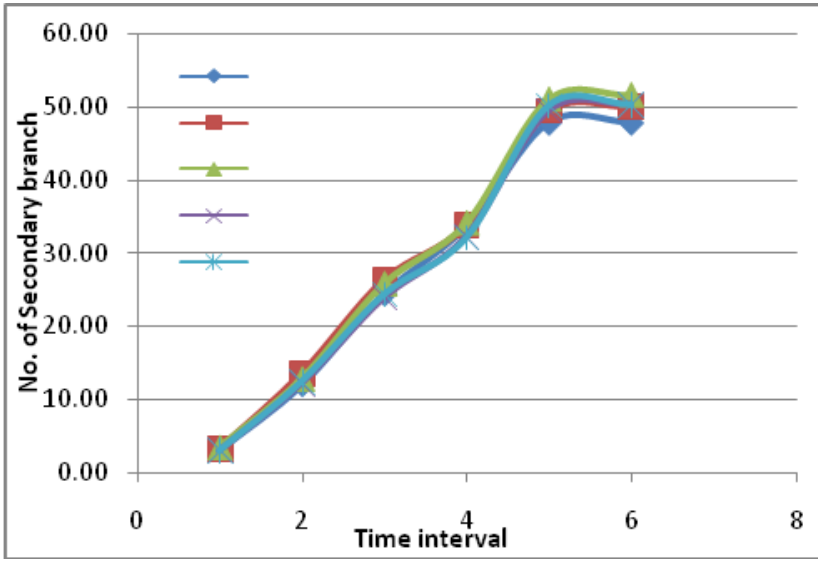

comparable to each other, whereas the lowest uptake of nitrogen was in 20 days dry spell at 40 days after sowing (56.79 kg ha-1). Moreover, higher phosphorus (7.58 and $\mathrm{kg}^{-} \mathrm{ha}^{-}$ $\left.{ }^{1}\right)$ and potash $\left(23.80 \mathrm{~kg} \mathrm{ha}^{-1}\right)$ were also noticed with control which was significantly superior over rest of treatments except irrigation at $20 \%$ soil moisture (6.89 and $22.75 \mathrm{~kg} \mathrm{ha}^{-1}$ ). The higher biomass accumulation is directly reflected in uptake of nitrogen. Mostly higher growth rate governs the uptake process which later diverts in reproductive parts. Better proliferation of roots and increased uptake of nutrients enhanced growth. Similar findings were also reported by Jyothi et al., (2013). As $\mathrm{K}$ is essential for grain development, the favourable effect of high doses of $\mathrm{K}$ on growth and yield attributes of wheat was mainly responsible for higher grain and biological yields. Application of irrigation water resulted in significantly higher available $\mathrm{K}$ and lower electrical conductivity EC and available than without irrigations. These finding confirm the results of Barzegar et al., (2003). This increase in $\mathrm{N}, \mathrm{P}$ and $\mathrm{K}$ uptake could be ascribed partly to variation in the availability of these nutrients in the soil and plants thus, ultimately increased uptake of this nutrient.

These findings were also similar to Dania et al., (2013) who observed in increasing trend. 
Allelo-chemicals can also decrease the ATP content of cells by inhibiting electron transport and oxidative phosphorylation which are two functions of mitochondrial membranes. In addition, allele-chemicals can alter the permeability of membranes to mineral ions (Balke, 1985).

\section{Yields of field pea}

Grain yield is submission of all parameters observed and recorded earlier periodic manner, which results as yield potential of treatment effect (Table 4). The grain yield was influenced significantly by different treatments, in which the maximum grain yield $\left(16.19 \mathrm{q} \mathrm{ha}^{-1}\right)$ was recorded with control (three irrigations) and found significantly superior as compared to other treatments except the two treatments viz., 20 days dry spell after 50\% flowering (16.03 $\left.\mathrm{q} \mathrm{ha}^{-1}\right)$ and irrigation at $20 \%$ soil moisture $\left(16.04 \mathrm{q} \mathrm{ha}^{-1}\right)$, which were statistically similar to control (three irrigations). Because of early dry spell shocked at just 40 days after sowing. The yield is directly dependent on various growth and yield parameters. Its expression was observed with their integrated influence with the increment in supply of moisture. After at critical stages and any moisture stress at these critical stages cause maximum yield reduction (Pal et al., 1996) by reducing the yield components. The present findings are in accordance with the findings of Idnani and Kumar (2012). The favourable effect of irrigation was in enhancing herb yield of field pea.

Haulm yield of field pea was maximum under control treatment $\left(36.60 \mathrm{qha}^{-1}\right)$ being comparable with irrigation at $20 \%$ soil moisture (34.19 q $\left.\mathrm{ha}^{-1}\right)$ and remaining treatments were not found comparable to these two treatments. The lowest haulm yield (27.79 $\mathrm{q} \mathrm{ha}^{-1}$ ) was recorded with 20 days dry spell at flower initiation, which was imposed by application of 20 days dry spell after $50 \%$ flowering (32.19 q ha $\mathrm{qu}^{-1}$ and at flower initiation $\left(31.75 \mathrm{q} \mathrm{ha}^{-1}\right)$, both were significantly higher in haulm yield over the lowest yield.

Harvest Index (HI) was also influenced by different dry spell treatments as observed in grain and haulm yields because $\mathrm{HI}$ is product of both yield calculation. The harvest index was maximum with control treatment $(33.85 \%)$ being statistically similar to irrigation at $20 \%$ soil moisture $(32.14 \%)$. However, 20 days dry spell at 40 DAS $(31.28 \%)$ and at flower initiation (30.42\%) were found comparable with each other. The lowest HI was noticed in 20 days dry spell at flowering (30.42\%). Profuse branching due to irrigation at $20 \%$ soil moisture increased interplant competition leading to higher dry matter with the same amount of grain yield, ultimately results in low harvest index.

\section{Economics}

Gross Monetary Returns (GMR) was influenced by various treatments imposed and showed significant differences among the dry spell treatments (Table 4). Field pea crop had higher GMR (Rs. 61768) when three irrigation (control) was applied and the control treatment was significant in achieving highest GMR compared to other treatments except irrigation at $20 \%$ soil moisture (Rs. 60778) comparable to each other in monetary gain. Among 20 days dry spell, dry spell imposed after 50\% flower coined higher GMR followed by 20 days dry spell at 40 DAS (Rs. 55550) and at flower initiation (Rs. 53130). Because higher grain yield in the treatments contributed for higher gross monetary returns.

Net monetary returns (NMR) also higher under three irrigations (Rs. 36629) which influenced by optimum soil moisture through frequent irrigation under particular treatment 
except 20 days dry spell after 50\% flowering (Rs. 32626) and irrigation at $20 \%$ soil moisture (Rs. 30193), which were statistically similar in obtaining comparatively higher NMR than rest of treatments. Grain and straw yields were the major factors which caused differences in net returns.

Involvement of cost and earning are basic components in calculation of benefit:cost ratio as influenced by different treatments of dry spell management, the highest $\mathrm{B}: \mathrm{C}$ ratio was recorded with control (2.01), being significantly superior and comparable to both 20 days dry spell after 50\% flowering (1.93) and irrigation at $20 \%$ soil moisture (1.89). The lowest B:C was noticed in 20 days dry spell at 40 days after sowing (1.82). This may be cause of lower cost of cultivation under reduced tillage and higher economic yield.

\section{References}

Amarakoon, U., Weerawardena, J., Verreynne, M. L. and Teicher, J. 2019. Entrepreneurial behaviour: a new perspective on the role of the HR professional. Personnel Review ahead-of-print (ahead-of-print). DOI: 10.1108/PR-03-2018-0087.

Andersen, M. N. and Aremu, J. A. 1991. Drought sensitivity root development and osmotic adjustment in field-grown peas. Irrigation Sci., 12: 45-51.

Anonymous. 2018. Annual Report 2017-18. Ministry of Agriculture \& Farmers welfare Department of Agriculture, cooperation and farmers welfare. Directorate of Pulses Development Vindhyachal Bhavan. pp. 1177.

Anonymous. 2018. Krishi Darshika, Annual publication of Directorate of Extension Services, IGKV, Raipur (C.G.) Pp. 6.

Anonymous. 2019. Annual Report 2019-2020. Directorate of economics and statistics data 2020-2021 govt. of Chhattisgarh.

Baishya, L. K., Kumar, M. and Ghosh, D. C. 2010. Effect of different production of organic and inorganic nutrients on productivity and profitability of potato (Solanum tuberosum L.) varieties in Meghalaya hills. Indian Journal of Agronomy 55(3): 230-34.

Balke, N. E., 1985. Effects of allelochemicals on mineral uptake and associated physiochemical process. The chemistry of Allelopathy, published by American chemical Society pp. 161-78.

Barzegar. A. R., Asoodar, M. A., Khalish, A., Hashemi, A. M. and Herbert, S. J. 2003. Soil physical characteristics and chickpea yield responses to tillage treatments. Soil and Tillage Research 71(1):49-57.

Boyer, J. S. 1982. Plant productivity and environment. Science, 218: 443-448.

Boyer, J. S. 1970. Leaf enlargement and metabolic rates in corn, soybean, and sunflower at various leaf water potentials. Plant Physiology, 46: 233-235.

Dahl, W. J., Foster, L. M. and Tyler, R.T. 2012. Review of the health benefits of peas (Pisum sativum L.). British Journal of Nutrition, 108:S3-S10. Doi:10. 1017/S0007114512000852.

Daie, J. 1998. Mechanism of drought induced alteration in assimilate partitioning and transport in crops. Critical Reviews in Plant Science, 2:117-137.

Embiale, A., Hussein, M., Husen, A., Sahile, S. and Mohammed, K. 2016. Differential Sensitivity of Pisum sativum L. Cultivars to Water-deficit Stress: Changes in Growth, Water Status, Chlorophyll Fluorescence and Gas Exchange Attributes. Journal of Agronomy, 15: 4557.

Flexas, Jaume and Medrano, Hipolito. 2002. Energy dissipation in C3 plants under drought. Functional Plant Biology 29(10):1209-1215

Fougereux, J. A., Doré, T., Ladonne, F. and Fleury, A. 1997. Water stress during reproductive stages affects seed quality and yield of pea (Pisum sativum L). Crop Science, 37(2): 1247-1252.

Ghoulam, C. and Fares, K. 2001. Effect of salinity on seed germination and early seedling growth of sugarbeet. Seed Sci. \& Technol., 29: 357-364.

Gomez, K. A. and Gomez, A. A. 1984. Statistical procedures for agricultural research. John 
wiley and sons, NewYork, 680p.

Hsiao, T. C. 1973. Plant responses to water stress. Annual Review of Plant Physiology, 24: 519-570.

Idnani, L. K. and Kumar, A. 2012. Relative efficiency of different irrigation schedules for conservation, ridge and raised bed seeding of wheat (Triticum aestivum). Indian Journal of Agricultural Sciences 57(2):148-51.

Iturbe-Ormaetxe, Inaki., Escuredo Pedro R., Arrese-Igor Cesar., and Becana, Manuel. 1998. Oxidative Damage in Pea Plants Exposed to Water Deficit or Paraquat. Plant Physiol. 116: 173-181.

Jyothi, C. N., Ravichandra, K. and Babu, K. S. 2013. Effect of foliar supplementation of nitrogen and zinc on soybean (Glycine $\max$ L.) yield, quality and nutrient uptake. Indian Journal of Dryland Agricultural Research and Development 28(2): 46-48.

Lawlor, D. W. and Cornic, G. 2002. Photosynthetic carbon assimilation and associated metabolism in relation to water deficits in higher plants. Plant, Cell and Environment 25: 275-294.

McPhee, K. 2004. Garden pea. Journal of New Seeds, 6: 277-288.

Pal, S. K., Singh, M. K., Thakur, R. and Verma, U. N. 1996. Effect of irrigation water scheduling time and fertilizer on wheat (Triticum aestivum L.) yield. Indian Journal of Agricultural Sciences 66 (3):177-79.

Pumphrey, F. V. and Schwanke, R. K. 1974. Effects of irrigation on growth, yield, and quality of peas for processing. J. Amer. Soc. Hort. Sci., 99:104-106.

Rao, K. V., Gangwar, S., Bajpai, A., Keshri, R., Chourasia, L. and Soni, K. 2017.Performance of pea under different irrigation system. Legume research,
40(3):559-661.

Riley, H. 1986. Drought periods at different growth stages of pea. Forsk. Fors. Landbr, 37:105-113.

Salter, P. J. 1962. Some responses of peas to irrigation at different growth stages. Journal of Horticultural Science, 37:141149.

Salter, P. J. 1963. The effect of wet and dry soil conditions at different growth stages on the components of yield of a pea crop. $J$. Hort. Sci., 38:321-334.

Salter, P. J. and Drew, D. H. 1965. Root growth as a factor in the response of Pisum sativum to irrigation. Nature, Lond. 206:10631064.

Semereet, T., Robert, J. and Williams, F. 2001. The effect of pea cultivar and water stress on root and shoot competition between vegetative plants of maize and pea. Journal of applied ecology, 38(1): 137145.

Singh, A. K. and Bhatti, B. P. 2013. Effect of foliar application of zinc on growth and seed yield of late sown lentil (Lens culinaris). Indian Journal of Agricultural Sciences 83(6):622-26.

Singh, R., Babu, S., Avasthe, R. K., Singh, A., Yadav, G. S., Pashte, V. and Singh, J. K. 2018. Screening of field pea varieties for rice-fallow areas under organic management in NE Himalayas. Ann. Agric. Res. New Series, 39(3):246-250.

Stoker, R. 1973. Response of viner peas to water during different phases of growth. New Zealand Journal of Experimental Agriculture, 9:73-76.

Uzun, A., Bilgili, U., Sincik, M., Filya, I. and Acikgoz, E. 2005. Yield and quality of forage type pea lines of contrasting leaf types. European Journal of Agronomy, 22:85-94.

\section{How to cite this article:}

Govind Pandey, A. Pradhan, M. Kumar, T. Chandrakar and Singh, D. P. 2021. Effect of Dry Spells on Growth and Yield of Field Pea under Irrigated Condition. Int.J.Curr.Microbiol.App.Sci. 10(06): 134-143. doi: https://doi.org/10.20546/ijcmas.2021.1006.014 